Discussion Paper No. 02-43

\title{
Does Experience Matter?
}

Innovations and the Productivity of ICT in German Services

Thomas Hempell

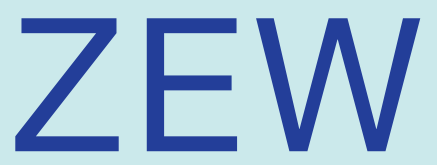

Zentrum für Europäische Wirtschaftsforschung $\mathrm{GmbH}$

Centre for European

Economic Research 
Discussion Paper No. 02-43

\title{
Does Experience Matter? \\ Innovations and the Productivity of ICT in German Services
}

\author{
Thomas Hempell
}

Download this ZEW Discussion Paper from our ftp server:

\begin{abstract}
ftp://ftp.zew.de/pub/zew-docs/dp/dp0243.pdf
\end{abstract}
Die Discussion Papers dienen einer möglichst schnellen Verbreitung von neueren Forschungsarbeiten des ZEW. Die Beiträge liegen in alleiniger Verantwortung der Autoren und stellen nicht notwendigerweise die Meinung des ZEW dar.

Discussion Papers are intended to make results of ZEW research promptly available to other economists in order to encourage discussion and suggestions for revisions. The authors are solely responsible for the contents which do not necessarily represent the opinion of the ZEW. 


\section{Non-technical summary}

In spite of emerging disillusions about a 'New Economy', productivity effects of information and communication technologies (ICT) continue to play a key role in assessing the prospects and growth potentials of both firms and whole economies. In fact, the economic downturn currently experienced by some countries shows that ICT are far from being a panacea that yields permanent growth and the end of business cycles, as some analysts suggested at the peak of the hype. Rather, there is growing support for the view that it is the specific economic and strategic circumstances within the individual firm that determine the success of using the new technologies.

Recent studies have indicated that ICT investment in businesses is closely linked with complementary organizational changes and innovations since the use of ICT enables firms to restructure their internal organization and to re-engineer business processes. In this study, it is argued that firms with innovative experience are particularly well prepared to make productive use of ICT by introducing appropriate complementary innovations. Administrations of firms that have introduced innovations in the past are expected to be better prepared to assess the potentials and limits of introducing major changes, they may be more successful in training and motivating their employees to take part actively in the subsequent innovations and they may have acquired some degree of innovative reputation in new business areas which facilitates the sale of new products and services.

The corresponding empirical analysis is based on a representative data set for German service firms covering the period 1994-99. The results reveal significant productivity effects of ICT and entail strong support for the hypothesis that the experience gained from past innovations is a specific complement that makes ICT investment more productive. In particular, innovative experience significantly enhances the productivity of ICT whereas complementary innovations alone do not exhibit such an impact. Obviously, the productive implementation of ICT requires rather a long-term innovation strategy than some ad-hoc implementation. Moreover, the quantitative effects of process innovation experience on ICT productivity are bigger than experience gathered from past product innovations. Finally, the dependence on innovative experience is found to be a feature that distinguishes ICT from conventional (non-ICT) capital. Thus, the increasing importance of innovations may well be identified as a key characteristic of the so called 'New Economy'.

One implication of the findings of this study is that the fast technical progress and diffusion of ICT have contributed to a widening of productivity differentials between firms. Since it is widely argued that innovative activities are closely linked to the business environment and policy framework within countries, these differentials at the firm-level may have led to a further widening of the productivity gap between highly innovative economies and less dynamic regions. 


\title{
Does Experience Matter? \\ Innovations and the Productivity of ICT in German Services $^{1}$
}

\author{
Thomas Hempell \\ Centre for European Economic Research (ZEW), Mannheim
}

July 2002

\begin{abstract}
In this paper, it is argued that ICT investment is closely linked with complementary innovations and most productive in firms with innovative experience. In an analysis based on firm-level panel data covering the period 1994-99, system GMM estimates for an extended production function framework reveal significant productivity effects of ICT in the German service sector. Moreover, there is strong support for the hypothesis that the experience gained from past process innovations is a specific feature that makes ICT investment more productive. The results suggest that ICT may have been contributing to productivity differentials between firms.
\end{abstract}

Keywords: Productivity, Information and Communication Technologies, Innovation, Services, Panel Data

JEL-Classification: C23, D24, L80, O32

Address: Centre for European Economic Research (ZEW)

Research Group of Information and Communication Technologies

P.O. Box 103443

D-68034 Mannheim

Germany

Phone: $\quad+49 / 621 / 1235-233$

Fax: $\quad+49 / 621 / 1235-225$

E-Mail: hempell@zew.de

\footnotetext{
${ }^{1}$ I greatfully acknowledge helpful comments by Irene Bertschek, Francesco Daveri, Paul David, Georg Licht, Werner Smolny, Kevin Stiroh, Elke Wolf and Thomas Zwick. I also thank the MIP team for providing me with the data. This paper draws on first results from an ongoing research project commissioned by the Landesstiftung Baden-Württemberg foundation.
} 


\section{Introduction}

In spite of emerging disillusions about a 'New Economy', productivity effects of information and communication technologies (ICT) continue to play a key role in assessing the prospects and growth potentials of both firms and whole economies. In fact, the economic downturn currently experienced by some countries shows that ICT are far from being a panacea that yields permanent growth and the end of business cycles, as some analysts suggested at the peak of the hype. Rather, there is growing support for the view that it is the specific economic circumstances that determine the success of using the new technologies. As emphasized by Bresnahan and Trajtenberg (1995) and Brynjolfsson and Hitt (2000), ICT serve primarily as 'enabling technologies' that require additional complementary innovation efforts to fully unfold their productivity potentials.

Various empirical studies support this view. In a study for 9 OECD countries, Colecchia and Schreyer (2001) find evidence that a rapid diffusion of ICT depends less on the existence of an ICT producing sector but rather on the flexibility of product and labour markets as well as the business environment. Referring to firm-level evidence, Brynjolfsson and Hitt (2000) emphasize the role of organizational changes that are prerequisites for an efficient ICT use. Brynjolfsson and Yang (1999) point to the role of intangible assets that are complementary to the firm's use of ICT. Bresnahan et al. (2002) find evidence for significant synergies between ICT, workplace reorganization and new services and products. These studies have an important message in common: in order to assess the impact of ICT it is crucial to investigate the firm-specific circumstances in which ICT are used.

The purpose of this paper is to shed more light on the factors that determine the success of productive ICT use. Unlike most previous studies of the topic, the theoretical model proposed in this study explicitly stresses the importance of ICT being part of the innovation process within a firm. With reference to evolutionary approaches in innovation theory it is argued that firms that have introduced innovations in the past are better prepared for ICT-induced innovations than firms without such innovation experience. As a consequence, the model predicts productivity effects of ICT to be higher in experienced firms.

Most previous empirical studies on the productivity effects of ICT have focussed on samples of large firms or firms from the manufacturing sector. However, ICT investment has been most dynamic and most extensive in volume in the service sector (OECD, 2000a). Moreover, as pointed out in OECD (2000b), business-related services have been the most important driver of economic growth over the last decades in the industrialized countries. The empirical analysis in this paper therefore draws on a representative survey among firms in business-related and distribution services.

The paper is organized as follows. In section 2, the theoretical background is discussed and 
the main theoretical hypotheses are implemented into a production function framework. Section 3 gives an overview of the data employed. Section 4 discusses the econometric issues and presents the empirical results for both a simple ICT-extended production function framework and the more specific model taking account of the role of innovative experience. Section 5 concludes with some comments on the implications of the findings.

\section{Theoretical Framework}

The theoretical background is based on the synthesis of two main ideas. First, evidence from recent studies indicates that the productive use of ICT is closely linked to complementary innovations within firms. In this paper, this link is hypothesized to be a special feature of ICT as opposed to other, more conventional types of capital. Second, it is argued that experience from past innovations raises a firm's absorptive capacity and flexibility to introduce innovations enabled by ICT. In the resulting model, both effects together lead to predicting a higher productivity of ICT within 'experienced' firms.

Apart from the broad and rapid diffusion of ICT, one of the most striking features of ICT is the wide scope of scope of coinventions possible from its use. According to Bresnahan and Trajtenberg (1995), ICT are essentially 'enabling technologies' that facilitate innovations in the application sectors. For example, computers have contributed to automate back-office operation, and network applications increasingly help to coordinate and integrate processes between establishments and firms. The close link between ICT investment and innovations might indeed be characterized as one of the features that distinguishes ICT as a general purpose technology from conventional capital. Recent studies yield empirical evidence for high complementarities between innovations and ICT use (see for example Brynjolfsson and Hitt, 2000; Bresnahan et al., 2002). Bresnahan and Greenstein (1996) argue that coinventions in ICT-using firms are anything but trivial and involve high adjustment costs and uncertainties. These costs of coinventions differ substantially between firms. This raises the question of which factors may help to explain these differences.

The investment in ICT is most intensive and most dynamic in services (see OECD, 2000a). In earlier studies on innovation, the service sector has been characterized as a mere applier of technological innovations developed in the manufacturing sector (see for example Pavitt, 1984). More recent empirical studies like Sirilli and Evangelista (1998), however, confirm a more active role of the service sector in the process of technological change as suggested by Barras (1986). Therefore, like in manufacturing, differences in technological opportunities, appropriability conditions, and cumulativeness of innovative capabilities may lead to differences in the innovation paths between 
firms in the service sector as well.

As pointed out by Cohen and Levinthal (1990), "the ability of a firm to recognize the value of new, external information, assimilate it, and apply it to commercial ends" (p. 128) is critical to its innovative capabilities. They argue that this 'absorptive capacity' is largely a function of the level of prior related knowledge. ${ }^{2}$ First, the absorptive capacity accumulated in a particular area in one period will permit a more efficient accumulation in the next. Second, 'experienced' firms will be able to better predict the nature and commercial potential of technological advances in an uncertain environment. Both aspects of absorptive capacity — cumulativeness and the impact on expectation formation - "imply that its development is domain-specific and is path- or history-dependent" (p. 136). Related studies by Mansfield (1968) and Stoneman (1983) argue that a firm's innovative success enhances its technological opportunities and thereby makes further success more likely. This 'success breeds success' hypothesis finds empirical support in a study by Flaig and Stadler (1994). They find that firms that have introduced innovations in the past are indeed more likely to innovate in subsequent years. Similar to these arguments and findings, innovative experience may be an important feature of firms to be better prepared than others to reap the potential benefits of ICT.

There are several more specific reasons supporting this view. First, managers are likely to have learned from past mistakes. ${ }^{3}$ They are better prepared to assess the potentials and limits of introducing major changes within their company, being aware of possible reactions of their employees and their traditional customers. This will reduce the risk of innovation projects to fail. Second, experienced firms are expected to be more efficient in implementing innovations. Their employees are more accustomed to adapting to new processes and internal reorganizations continuously and may be more easily motivated and trained for new tasks and work practices. Moreover, experienced firms may have a higher share of employees that accept an intensive use of ICT at their workplace. This may be due to both special recruitment strategies and to specific experience of the workforce from former innovation activities. ${ }^{4}$ Finally, innovative firms may have aquired some degree of 'innovative

\footnotetext{
${ }^{2}$ Building on studies in cognitive and behavioral sciences, Cohen and Levinthal (1990) state that at the level of individuals, "learning is cumulative, and learning performance is greatest when the object of learning is related to what is already known" (p. 131). At the level of organizations, for example firms, the absorptive capacity is not just the sum of absorptive capacities of its individual employees but also depends on the transfer of knowledge across and within subunits. As a consequence, there is a trade off between the aim of highly diversified capacities of the individuals in order to recognize the value of various new external information on the one hand, and the need of specialization or a "shared language" to ensure the transfer of knowledge within the organization. Therefore, the effect of specialization on the learning effect at the level of firms is ambiguous.

${ }^{3}$ The returns to innovations are far from being safe. However, the likelihood of a success may increase with the experience gathered from past innovations. In this regard, the learning process in introducing innovations may be compared to the search model proposed by Nelson (1982) for the case of R\&D. Innovation is modelled as a search process in which knowledge helps to lower the search costs by focussing search on more relevant alternatives.

${ }^{4}$ Nelson and Winter (1982) suggest that much of the knowledge of a firm's organizational routines and objectives is tacit. They summarize this observation by claiming that organizations 'remember by doing'. Thus, innovational capabilities are difficult to raise by hiring new personnel. Also in this regard, the firm's innovative history plays a key
} 
reputation' or branding in new business areas, which in turn might facilitate the attraction of new customers by exploiting ICT-based sales channels (B2B, B2C) or by introducing new ICT-based services or products. .5

These arguments entail two specific hypotheses. First, innovative experience is an important prerequisite for implementing ICT efficiently. Second, other (conventional) capital inputs are much less linked to complementary innovation and the dependence on innovative experience makes ICT a 'special' type of capital.

In order to derive a framework that allows for the assessment these hypotheses empirically, the traditional Cobb-Douglas production setup is used as a starting point:

$$
Y_{i t}=F\left(A_{i}, K_{i t}, L_{i t}\right)=A_{i} L_{i t}^{\gamma_{1}} K_{i t}^{\gamma_{2}}
$$

where $Y_{i t}$ is value added of firm $i$ in period $t, K_{i t}$ is the corresponding conventional (non-ICT) capital, $L_{i t}$ represents effective labour and $A_{i t}$ is the multifactor productivity of firm $i{ }^{6}$ ICT capital does not enter the production function directly, but rather affects multifactor productivity jointly with innovative experience as a complement:

$$
A_{i t}=A\left(I C T_{i t}, E_{i}, m_{i}\right)
$$

where $A_{i t}$ represents firm's $i$ multifactor productivity at time $t, I C T_{i t}$ represents its amount of ICT capital, $E_{i}$ innovative experience and $m_{i}$ collects other unobserved efficiency parameters of firm $i$ like management skills, location, branding, etc. Since the time interval considered in the empirical application is relatively short (6 years), experience $E_{i}$ and other unobserved factors $m_{i}$ are assumed to be time-invariant. Furthermore, the following three properties of function $A(\bullet)$ are imposed. A firm's productivity depends positively on both ICT input and innovative experience $\left(\partial A_{i t} / \partial I C T_{i t} \geq 0, \partial A_{i t} / \partial E_{i} \geq 0\right)$ and, most importantly, the productivity contributions of ICT are increasing with the degree of innovative experience: $\partial^{2} A_{i t} / \partial I C T_{i t} \partial E_{i} \geq 0$. A convenient functional form satisfying these properties is:

$$
A_{i t}=C \cdot m_{i} \cdot I C T_{i t}^{x\left(E_{i}\right)}
$$

with $C$ as a common scale factor and $x\left(E_{i}\right)$ being a strictly monotone function. Past innovation activities are considered as a proxy of a firm's innovative experience such that $E_{i}=1$ if firm $i$ has role (see Cohen and Levinthal, 1990).

${ }^{5}$ Smith and Brynjolfsson (2001) find that brand is an important determinant of consumer choice in internet transactions. They find that "consumers use brand as a proxy for retailer credibility in non-contractible aspects of the product and service bundle, such as shipping reliability" (p. 541). Interestingly, in the study the strongest brand effect was found for amazon, which has gained reputation as one of the leading internet retailers.

${ }^{6} F(\bullet)$ may be such that $\mathrm{Y}$ exhibits constant returns to scale in $\mathrm{K}$ and $\mathrm{L}\left(\gamma_{1}+\gamma_{2}=1\right)$, but not necessarily. 
been an innovator in the earliest available period and $E_{i}=0$ otherwise. Denoting $x(0)=x$ and $x(1)=x+\Delta x$, the main hypothesis reduces to $\Delta x>0$. Then equation (3) may be transformed to:

$$
A_{i t}=C \cdot m_{i} \cdot I C T_{i t}^{x+\Delta x \cdot E_{i}}
$$

Inserting equation (4) into (1) and taking logs then yields the following extended production function equation:

$$
\ln Y_{i t}=\ln C+\ln m_{i}+x \ln I C T_{i t}+\Delta x\left(E_{i} \cdot \ln I C T_{i t}\right)+\gamma_{1} \ln L_{i t}+\gamma_{2} \ln K_{i t}
$$

Thus, the model corresponds to an ICT-extended Cobb-Douglas function except that the coefficient of ICT (reflecting the corresponding elasticity of output) is predicted to be higher in firms with experience in innovation $(\Delta x>0)$. In the context here, this is equivalent to saying that there are more potential benefits to be exploited by the use of ICT within innovative firms. ${ }^{7}$ In particular, for any given share of ICT capital in output $(I C T / Y)$, the marginal product of ICT will be higher in experienced firms. ${ }^{8}$ Since marginal products of ICT (MPI) should be equal across all firms (that is ICT is earning equal returns), a further implication is that experienced firms will produce their services with a higher ICT intensity $\left(I C T_{i t} / Y_{i t}=(x+\Delta x) / M P I_{i t}\right)$ than non-experienced firms $\left(I C T_{i t} / Y_{i t}=x / M P I_{i t}\right)$.

Finally, in order to specify an econometrically testable model, two further aspects are taken into account. First, apart from raising a firm's innovative experience and the productivity of ICT use, past innovations captured by the variable $E_{i}$ are likely to have direct and persistent effects on a firm's productivity for several periods as well. In particular, an important intended result of innovation may be cost reductions due to restructuring processes or price increases through product innovations, both leading to an increased productivity of measured inputs. In order to isolate these direct effects on productivity from the specific role of innovative experience in ICT use, $E_{i}$ is considered as an additional explanatory variable in the model. Second, in order to be more specific about the hypothesis of ICT being a 'special' capital input, a further term is included that interacts conventional capital with innovative experience. The coefficient of this interaction term is expected to be zero while the coefficient of the corresponding interaction of ICT and experience is predicted

\footnotetext{
${ }^{7}$ For the regular case, in which the output elasticity with respect to a single input is positive and smaller than unity, the marginal returns to ICT, $\partial Y_{i t} / \partial I C T_{i t}$, will decrease when the use of ICT is increased and the use of the other factors is held constant: $0<x\left(E_{i}\right)<1 \Rightarrow \partial^{2} Y_{i t} / \partial I C T_{i t}^{2}=x\left(E_{i}\right) \cdot\left(x\left(E_{i}\right)-1\right) \cdot Y_{i t} / I C T_{i t}^{2}<0$. However, the marginal product of ICT is decreasing less rapidly in firms with a higher elasticity $x\left(E_{i}\right)$. In this sense, there are more potential benefits from the use of ICT in experienced firms.

${ }^{8}$ Formally, the marginal returns to ICT (MPI) are the product of the output elasticity of ICT and the inverse ratio of ICT capital in output: $M P I_{i t}=\partial Y_{i t} / \partial I C T_{i t}=x\left(E_{i}\right) \cdot Y_{i t} / I C T_{i t}$. Therefore, $M P I_{i t}$ increases with the output elasticity $x\left(E_{i}\right)$, but decreases with the share of ICT capital in output $I C T_{i t} / Y_{i t}$.
} 
to be positive in a simultaneous estimation. With these extensions, equation (5) is transformed into the following econometric model:

$$
\begin{aligned}
\ln Y_{i t}= & c+\beta_{1} \ln L_{i t}+\beta_{2} \ln I C T_{i t}+\beta_{3} \ln K_{i t} \\
& +\beta_{4} E_{i}+\beta_{5}\left(\ln I C T_{i t} \cdot E_{i}\right)+\beta_{6}\left(\ln K_{i t} \cdot E_{i}\right)+\eta_{i}+\epsilon_{i t}
\end{aligned}
$$

with $c=\ln C, \eta_{i}=\ln m_{i}, \beta_{1}=\gamma_{1}, \beta_{2}=x, \beta_{3}=\gamma_{2}, \beta_{5}=\Delta x$ and $\epsilon_{i t}$ as a normally distributed disturbance term. In this framework, the question about innovative experience influencing the productivity of ICT use hinges on two coefficients: a significantly positive $\beta_{5}$ would indicate that experience matters indeed, while an insignificant $\beta_{6}$ would stress the special role of ICT as opposed to conventional capital in this context.

\section{The Data}

In order to implement the production framework empirically, data from the Mannheim Innovation Panel in Services (MIP-S) is employed. This survey is conducted by the Centre for European Economic Research (ZEW) on behalf of the German Federal Ministry for Education and Research $(\mathrm{bmb}+\mathrm{f})$. The data is based on an annual representative survey of innovation activities in the German business-related service and distribution sector and includes information of more than 2000 firms (see Janz et al., 2001). The survey methodology is closely related to the guidelines proposed in the Oslo-Manual on innovation statistics (OECD/Eurostat, 1997). The employed data has an unbalanced panel structure in important key variables for the years 1994-99.

For the particular purpose of the empirical investigation, the MIP-S data set contains annual data on sales, number of employees as full-time equivalents, skill structures, expenditures for gross investment and for ICT-capital (hardware, software and telecommunication technology) as well as product and process innovations and location. In order to estimate the model equation, several data transformations were necessary. ${ }^{9}$ Figures on firm sales have been deflated using deflators at the two-digit level from the German statistical office. Since the data set does not contain information on intermediate goods, the firms' value added has been approximated by multiplying firms' sales with the two-digit industry's average share of value added in gross output based on data published by the German statistical office. Labour input is measured by the number of employees as full-time equivalents. Moreover, the survey contains data on the skill level of the workforce. In the estimations, the shares of employees with university degree and with vocational training are used. Since there are high rates of item non-responses in the skill variables, ${ }^{10}$ however, the

\footnotetext{
${ }^{9}$ Both the data set and the transformations using industry-level data are described in more detail in Hempell (2002).

${ }^{10}$ Only 591 of the 1222 firms of the sample reported information on the skill structure of their employees.
} 
resulting "small sample" containing this information is just used to explore the effects of omitted human capital variables. Capital stocks for ICT capital and conventional (non-ICT) capital were constructed separately. For this purpose, investment on conventional capital was defined as total investment expenditures minus ICT expenditures as taken from the survey 11 For deriving real conventional investment, deflators of the German Statistical office at the two-digit industry level were used ${ }^{12}$ whereas in the case of ICT investment, internationally harmonized deflators provided by Schreyer (2000) are applied! ${ }^{[3}$ Given the deflated investments for both types of capital, the capital stocks for ICT and non-ICT were constructed separately by the perpetual inventory. The methodological details are discussed in the appendix A. For a comprehensive description of the data base, see Hempell (2002).

The theoretical considerations of the previous section suggest that productivity of ICT use is higher in firms with innovative experience. This experience is approximated using information on innovation effort contained in the MIP-S survey. In each wave, firms were asked whether they had introduced new or significantly improved services and/or new processes. These questions refer to a past 3-year-period, including the reference year of the survey. Using these two variables and applying two distinctions, a total of four different classifications of firms are constructed to measure a firm's innovative experience. According to a first (broad) distinction, a firm is classified as a "panel product innovator" (PPD) or "panel process innovator" (PPC) if it had declared itself an innovator in at least one of the periods surveyed. By contrast, according to a second, narrower definition, a firm is denoted as an "experienced product innovator" or an "experienced process innovator" (EPD or EPC respectively) if and only if it has declared itself an innovator in the first of the periods in which it participated in the survey. ${ }^{14}$ This means that an experienced firm has introduced the corresponding innovation up to two years before the time interval for which productivity effects are analyzed. This more restrictive definition focusses on innovation experience as a history-oriented concept. Moreover, the possible endogeneity of the innovation decision is controlled for by a clear temporal sequence (the innovation decision preceding decisions about inputs and output analyzed). In contrast, the broader definition will rather reflect a firm's ad-hoc introduction of innovations. By comparing the results for both definitions of innovative activity, it should be possible to conclude whether it is really experience that matters for the output contribution of ICT or whether it is the

\footnotetext{
${ }^{11}$ Some 70 firms reported investment expenditures in ICT that exceeded total investment and were excluded from the sample.

${ }^{12}$ The index of the producer prices for investment goods from the Statistical Yearbooks with 1996 as the base year was employed for this purpose.

${ }^{13}$ German official price statistics on ICT goods tend to understate the real price decline of this product class as pointed out by Hoffmann (1998). By contrast, Schreyer (2000) takes this bias into account by calculating a harmonized price index for various OECD countries. He employs official statistics ICT prices in the U.S., which are based on hedonic techniques, as a reference and assumes that the differences between price changes for ICT and non-ICT capital goods are the same across countries.

${ }^{14}$ Note that an "experienced innovator" must also be a "panel innovator".
} 
effect of rather ad-hoc innovations.

The sample used for the estimation contains only firms with consistent information on at least three consequent periods. The resulting unbalanced sample consists of 1222 firms with a total of 5107 observations. This corresponds to an average of 4.2 observed periods per firm. As illustrated in the summary statistics of Table 2 in the appendix, the majority of firms in the sample are small and medium size firms with a median of 40 employees. $10 \%$ of the sample consists of large firms with more than 500 employees, including some firms with several tens of thousands of employees. This leads to a mean number of employees around 600 . The mean shares of innovating firms according to different classifications are summarized by industries in Tables 3 and 4. Tables 5 and 6 show that the sample reflects industry and size structure of the German business-related and distribution services fairly well ${ }^{15}$ Finally, in Table 7, the (cross-sectional) means and medians of the firms' (longitudinal) averages of capital and output intensity (measured in capital per employee) are displayed for the firms in the sample. ${ }^{16}$ The figures indicate that in the median firm of the sample, a workplace is equipped with 1300 Euro of ICT capital, and with about 25,600 Euro of non-ICT capital. The median value added per employee is around 60,600 Euro.

The summary statistics both in absolute value and in per capita terms indicate that the share of ICT capital in the total capital stock is very low. Comparing the medians of ICT per worker and conventional capital per worker in Table 7, ICT endowment amounts to $4.8 \%$ in total endowment. Similarly, aggregating the firms' time-averages of both types of capital yields a share of ICT capital in total capital of $5 \%$ (not reported in the tables). These values correspond very well to the share of $3 \%$ calculated by Schreyer (2000) using aggregate data for Germany (including the less ICT-intensive manufacturing sector) in 1996. As argued by Griliches (1994), such small shares of ICT input together with measurement errors may make it difficult to distinguish the output contributions of ICT from stochastic events and may make the identification of productivity effects of ICT resemble the search for the "needle in the haystack".

The distinction between firms according to their innovation experience may help to alleviate this problem. As reported in columns 2 and 3 of Table 7 , the distinction according to firms' innovative experience may help to identify the productivity effects. ${ }^{17}$ In fact, the mean of the per capita value of ICT stock in experienced firms (defined according to its narrow definition)

\footnotetext{
${ }^{15}$ Retail trade is slightly undersampled whereas traffic and postal services as well as software and telecommunication are slightly oversampled. As far as firm size is concerned, large firms are oversampled in their mere number and undersampled in their respective share in sales (see last two columns of Table 6).

${ }^{16}$ The corresponding mean values are substantially higher than the median since some firms - in particular of real estate - display very high values for both inputs and output per employee.

${ }^{17}$ To simplify the table, only one distinction (according to experience in process innovations) is reported. The qualitative results are very similar when the other classification of innovators are employed.
} 
exceeds the corresponding value of non-experienced firms by a factor of about 1.5. This difference is even more pronounced (factor 2.3) if median values are compared. In contrast, the per capita values of output and conventional capital are slightly higher among non-experienced firms. These simple summary statistics support the outlined hypotheses: if ICT use is more productive in experienced firms, these firms will tend to spend a higher amount on ICT per worker than other firms.

\section{Empirical Results}

In order to estimate the empirical model of equation 6 consistently the system GMM (SYS-GMM) estimator developed by Arellano and Bover (1995) is applied. In this estimation strategy, the GMM estimator in first differences proposed by Arellano and Bond $(1991)^{18}$ is extended by the estimation equation in levels instrumented by suitably lagged differences of the explanatory variables. These two specifications are then estimated simultaneously. ${ }^{19}$ This estimator controls for unobserved firm effects, measurement errors in the variables and simultaneity of inputs and output which may induce substantial biases in pooled or within OLS regressions (see Hempell, 2002). Moreover, since the variables are highly persistent, the additional moment restriction obtained from the inclusion of the equation in levels substantially improves the performance of the Arellano-Bond-estimator (see Blundell and Bond, 1998a). In order to control for variations in factor utilization induced by industry-specific business cycles, dummies for 7 industries ${ }^{20}$ interacted with years have are added to the specification. Finally, a dummy variable for East German firms is supposed to control for the productivity differentials due to the transformation process after German unification. For a thorough discussion of all the the underlying econometric issues, see Hempell (2002).

The corresponding results from applying the two-step SYS-GMM estimator are reported in Table 1. ${ }^{21}$ In the first column, the results for the simple ICT-augmented production function are reported as a reference. In particular, no distinction has been made between experienced and non-experienced firms. In this specification, all three factor inputs are significantly positive. The

\footnotetext{
${ }^{18}$ In this strategy, the estimation equation in first differences is instrumented by all the suitably lagged levels of the regressors and estimated by GMM.

${ }^{19}$ The additional moment conditions required for the equation in levels are not very restrictive. As shown by Blundell and Bond (1998b), only weak assumptions about the initial distribution of the variables used are necessary. In particular, the joint stationarity of the dependent and the independent variables is a sufficient, yet not necessary condition for the validity of the moment conditions for the equation in levels.

${ }^{20}$ These are (with the corresponding NACE codes in brackets): wholesale trade $(51)$, retail trade $(50,52)$, transport and postal services (60-63, 64.1), electronic data processing and telecommunications $(72,64.2)$, consultancies (74.1, $74.4)$, technical services $(73,74.2,74.3)$, and other business-related services $(70,71,74.5-74.8$, 90). Since there are no output data available for banking and insurance (only the balance sheet total and insurance premiums respectively), these industries must be excluded from the analysis.

${ }^{21}$ All estimations were computed using the DPD98 programme developed by Arellano and Bond (1998) running in GAUSS. For all results, heteroscedasticity-consistent standard errors are reported.
} 
output elasticity of labour amounts to two thirds which is consistent with the share of income from labour in the aggregate statistics. The coefficients of ICT and non-ICT capital amount to $4.9 \%$ and $18.9 \%$ respectively. However, the coefficient of ICT capital is only marginally different from zero (p-value=0.058). ${ }^{22}$ As expected, East-German firms in services are significantly less productive than their West-German counterparts. The coefficient of the East-Dummy (roughly -0.4) implies that the multifactor productivity in East-German firms were only about two-thirds of the West-German level in the period observed. This finding coincides with aggregate statistics on productivity differentials in Germany. The corresponding Sargan-statistic $(p=0.193)$ does not reject the validity of the instruments at the usual significance levels. These results point to substantial output contributions of ICT in the German service sector.

One might object that these results are likely to be biased due to the omission of explanatory variables in the regression specification. In particular, empirical studies like Bresnahan, Brynjolfsson and Hitt (2002) find that ICT use is closely linked to a more intensive use of skills. On the one hand, omitting skills in the regression might therefore lead to an overestimation of the true impacts of ICT use if the output contributions of skills are then (wrongly) assigned to the mere use of ICT. On the other hand, the skill structure as well as other potential inputs not included in the regression may be quite persistent over the time interval observed. Thus, the largest variation in these variables will be between firms and their effect will not be distinguishable from firm effects which are controlled by the SYS-GMM estimator. If this last argument prevails, the omission of these variables in the estimation equation will not bias the results. To assess this question empirically, the subsample of 591 firms, for which data on skill structure are available, is employed. The main finding is that including the share of employees with university degree and vocational training yields highly significant coefficients for these variables but has no effect on the ICT coefficients (see Table 8 in the appendix) ${ }^{23}$ This result is similar to the findings by Lehr and Lichtenberg (1999). Therefore, no distortion of the results is to be expected from omitting human capital in favour of a more comprehensive sample of observations.

In the second column of Table 1, the results are reported for the specification in which a 'surplus' of ICT contributions $(\Delta x)$ is allowed for in firms with experience in introducing process innovations

\footnotetext{
${ }^{22}$ In the one-step estimation, the p-value of the ICT-coefficient amounts to 0.106 only. As argued in Blundell and Bond (1998b) on the basis of Monte Carlo simulations, "[i]nference based on one-step GMM estimators appears to be much more reliable when either non-normality or heteroskedasticity is suspected" (142). Therefore, the results for the one-step significance levels are added in footnotes if these differ substantially from the two-step inferences reported in Table 1 .

${ }^{23}$ In both these specifications, the ICT coefficient is very low and insignificant. This result may be due to the different firm structure in the subsample. In particular, the average firm size in the reduced sample (99.6 employees) is only a sixth compared to the full sample. A further source, however, may be the increased imprecision of the estimates due to the loss of more than half of the observations available in the full sample.
} 
Table 1: The role of innovative experience

\begin{tabular}{|c|c|c|c|c|c|c|c|c|}
\hline \multirow[b]{3}{*}{ inputs $(\operatorname{logs})$} & \multicolumn{8}{|c|}{ Dep. Variable: sales (logs) } \\
\hline & (1) & $(2)$ & $(3)$ & $(4)$ & $(5)$ & $(6)$ & (7) & (8) \\
\hline & overall & epc & epd & epc \& epd & $\mathrm{ppc}$ & ppd & epc & epd \\
\hline labour & $\begin{array}{c}0.686^{* * *} \\
(0.058)\end{array}$ & $\begin{array}{c}0.639^{* * *} \\
(0.055)\end{array}$ & $\begin{array}{c}0.652^{* * *} \\
(0.058)\end{array}$ & $\begin{array}{c}0.624^{* * *} \\
(0.054)\end{array}$ & $\begin{array}{c}0.668^{* * *} \\
(0.057)\end{array}$ & $\begin{array}{c}0.693^{* * *} \\
(0.058)\end{array}$ & $\begin{array}{c}0.600^{* * *} \\
(0.056)\end{array}$ & $\begin{array}{c}0.611^{* * *} \\
(0.058)\end{array}$ \\
\hline ICT capital & $\begin{array}{l}0.049^{*} \\
0.026)\end{array}$ & $\begin{array}{c}0.027 \\
(0.026)\end{array}$ & $\begin{array}{c}0.009 \\
(0.027)\end{array}$ & $\begin{array}{c}0.004 \\
(0.027)\end{array}$ & $\begin{array}{c}0.036 \\
(0.033)\end{array}$ & $\begin{array}{c}0.022 \\
(0.035)\end{array}$ & $\begin{array}{l}0.036 \\
(0.023)\end{array}$ & $\begin{array}{l}0.025 \\
(0.026)\end{array}$ \\
\hline non-ICT capital & $\begin{array}{c}0.189^{* * *} \\
(0.036)\end{array}$ & $\begin{array}{c}0.186^{* * *} \\
(0.036)\end{array}$ & $\begin{array}{c}0.189^{* * *} \\
(0.037)\end{array}$ & $\begin{array}{c}0.185^{* * *} \\
(0.036)\end{array}$ & $\begin{array}{c}0.198^{* * *} \\
(0.035)\end{array}$ & $\begin{array}{c}0.201^{* * *} \\
(0.035)\end{array}$ & $\begin{array}{c}0.197^{* * *} \\
(0.055)\end{array}$ & $\begin{array}{c}0.161^{* * *} \\
(0.056)\end{array}$ \\
\hline $\begin{array}{l}\text { process innovator } \\
\text { (pc) }\end{array}$ & - & $\begin{array}{c}0.263^{* * *} \\
(0.100)\end{array}$ & - & $\begin{array}{l}0.205^{* *} \\
(0.095)\end{array}$ & $\begin{array}{l}0.045 \\
(0.137)\end{array}$ & - & $\begin{array}{c}0.280^{* *} \\
(0.141)\end{array}$ & - \\
\hline ICT cap. *pc & - & $\begin{array}{c}0.125^{* * *} \\
(0.039)\end{array}$ & - & $\begin{array}{r}0.089^{* *} \\
(0.038)\end{array}$ & $\begin{array}{c}0.018 \\
(0.037)\end{array}$ & - & $\begin{array}{c}0.104^{* * * *} \\
(0.039)\end{array}$ & - \\
\hline non-ICT cap. *pc & - & - & - & - & - & - & $\begin{array}{l}-0.021 \\
(0.068)\end{array}$ & - \\
\hline $\begin{array}{l}\text { product innovator } \\
\text { (pd) }\end{array}$ & - & - & $\begin{array}{l}0.196^{*} \\
(0.108)\end{array}$ & $\begin{array}{l}0.128 \\
(0.105)\end{array}$ & - & $\begin{array}{c}0.014 \\
(0.142)\end{array}$ & 一 & $\begin{array}{c}0.152 \\
(0.146)\end{array}$ \\
\hline ICT cap.*pd & - & - & $\begin{array}{l}0.089^{* *} \\
(0.035)\end{array}$ & $\begin{array}{l}0.058^{*} \\
(0.034)\end{array}$ & - & $\begin{array}{l}0.016 \\
(0.037)\end{array}$ & - & $\begin{array}{l}0.069^{*} \\
(0.037)\end{array}$ \\
\hline non-ICT cap.*pd & - & - & - & - & - & - & - & $\begin{array}{l}0.037 \\
(0.074)\end{array}$ \\
\hline East-Germany & $\begin{array}{c}-0.384^{* * *} \\
(0.045)\end{array}$ & $\begin{array}{c}-0.367^{* * *} \\
(0.045)\end{array}$ & $\begin{array}{c}-0.378^{* * *} \\
(0.043)\end{array}$ & $\begin{array}{c}-0.371^{* * *} \\
(0.044)\end{array}$ & $\begin{array}{c}-0.389^{* * *} \\
(0.044)\end{array}$ & $\begin{array}{c}-0.395^{* * *} \\
(0.044)\end{array}$ & $\begin{array}{c}-0.371^{* * *} \\
(0.045)\end{array}$ & $\begin{array}{c}-0.381^{* * *} \\
(0.044)\end{array}$ \\
\hline observations & 5107 & 5107 & 5107 & 5107 & 5107 & 5107 & 5107 & 5107 \\
\hline firms & 1222 & 1222 & 1222 & 1222 & 1222 & 1222 & 1222 & 1222 \\
\hline $\mathrm{R}$-square & 0.836 & 0.837 & 0.835 & 0.837 & 0.836 & 0.836 & 0.836 & 0.834 \\
\hline $\begin{array}{l}\text { Wald stat.[df]: } \\
\text { inputs }\end{array}$ & $609[4]$ & $1040[6]$ & $856[6]$ & $1058[8]$ & $828[6]$ & $732[6]$ & $1047[7]$ & $865[7]$ \\
\hline $\begin{array}{l}\text { time \& ind. } \\
\text { dummies }\end{array}$ & $685[41]$ & $737[41]$ & $722[41]$ & $743[41]$ & $723[41]$ & $733[41]$ & $744[41]$ & $684[41]$ \\
\hline $\begin{array}{l}\text { Sargan ( } \mathrm{p} \text {-values) } \\
\text { errors ( } \mathrm{p} \text {-values): }\end{array}$ & 0.193 & 0.199 & 0.198 & 0.210 & 0.449 & 0.200 & 0.126 & 0.177 \\
\hline $\mathrm{AR}(1)$ & 0.003 & 0.003 & 0.003 & 0.003 & 0.003 & 0.003 & 0.004 & 0.004 \\
\hline $\operatorname{AR}(2)$ & 0.039 & 0.049 & 0.052 & 0.059 & 0.044 & 0.041 & 0.060 & 0.068 \\
\hline
\end{tabular}

***,**, ${ }^{*}=$ significant at the 1,5 and 10 per cent level. All regressions are based on the two-step SYS-GMM estimator and contain a constant as well as interacted industry and year dummy variables. Heteroscedasticity consistent standard errors reported.

according to the narrow definition (epc). The most striking result is that the ICT coefficient, in fact, differs significantly between experienced and non-experienced firms. For experienced process innovators (epc), an implicit output elasticity of $15.2 \%$ is found.24 The difference to the nonexperienced firms is highly significant, yielding strong support for the important role of innovative experience in ICT use. In contrast, the corresponding ICT coefficient for not experienced firms

\footnotetext{
${ }^{24}$ Note that the estimated ICT coefficient for innovators (ICT cap ${ }^{*} \mathrm{pc}$ ) represents the difference between the elasticities of experienced and non-experienced firms $\Delta x$ (see equations 5 and 6 ). The implicit ICT elasticity of the experienced firms $x(1)=x(0)+\Delta x$ is just the sum of the two ICT coefficients.
} 
is quite low $(3.2 \%)$ and insignificant. Interestingly, the dummy for process innovation experience is highly significant as well. Obviously, beyond the importance for ICT use, there are also direct benefits from new processes introduced in the past. The size of 0.263 of the epc-dummy implies that, on average, firms with process innovation experience are about $30 \%$ more productive than other firms. Beyond experience, this productivity advantage may well be a direct consequence of the process innovations in the past. Compared to the SYS-GMM results in the first column, the other coefficients are hardly affected by the additional variables included in the regression, which points to the robustness of the results.

In the third column of Table 1, the results for the corresponding distinction of firms according to their experience of product innovations (epd) are reported. The results are very similar to those in column 1. However, the coefficient marking the difference in ICT contributions is significant at the $10 \%$ level ${ }^{25}$ The implicit output elasticity for epd-firms $(9.3 \%)$ is considerably smaller than in the regression with the classification according to process innovation experience (epc) ${ }^{26}$ Given that more than $70 \%$ of the product innovators are also experienced in process innovations (see Table 3), this difference may be a consequence of the simultaneous process innovation experience rather than the experience collected through product innovations. As a first preliminary result, it may be concluded that past process innovations have the biggest impact on a firm's productive use of ICT.

This interpretation finds further support in the results reported in column 4 . In this specification, different ICT-coefficients for experience in both process and product innovations are estimated simultaneously. The ICT-coefficient of experienced process innovators (0.089) substantially exceeds the corresponding coefficient for experienced product innovators (0.058). The latter coefficient is significantly different from zero only at the $10 \%$-level. This finding entails more support for the particular importance of experience from process innovations. ${ }^{27}$ The ICT-coefficient is virtually zero for firms which possess without any innovation experience.

Is it really innovative experience that matters, or are complementary innovations in general the key factors for a productive use of ICT? In order to explore this question, the results for the less restrictive definition of firms with some process innovation ("panel process innovators", ppc) or product innovation ("panel product innovators", ppd) are reported in columns 5 and 6 . As discussed in section $[3$, this wider definition captures both firms with innovative experience and firms that have introduced innovations at a later point in time during the period observed. Therefore,

\footnotetext{
${ }^{25}$ The one-step estimation, however, indicates a higher significance level $(\mathrm{p}=0.038)$ (see footnote 22 ).

${ }^{26} \mathrm{~A}$ further difference to the preceding results is that there are no significant direct productivity effects resulting from past product innovations.

${ }^{27}$ Based on the one-step inference, however, neither of the three ICT coefficients (epc, epd and others) is significantly different from zero (see footnote 22).
} 
apart from rather long-term 'experience', this classification variable also includes short-term implementation strategies. The results for this specification show no significant difference between innovators and other firms regarding the productivity of use of ICT. This finding suggests that it is indeed the experience generated by a firm's innovation history that facilitates an efficient ICT use.

Apparently, ICT productivity is particularly high in firms with experience in process innovation. But, is this a special feature of ICT as opposed to conventional capital? In order to address this question, non-ICT capital interacted with the dummy for experienced process innovators has been added to the regressors in a further specification (col. 7 in Table 1 ). ${ }^{28}$ The results show that, in fact, there is a remarkable difference between both types of capital. While ICT capital — like in column 2 - continues to be more productive in experienced firms, no such difference can be observed in the case of conventional capital. The implicit ICT coefficient of epc-firms (14\%) is very similar to the results from column 2. Moreover, the difference between the coefficients of experienced and other firms is now significant even at the $1 \%$ level.$^{29}$ In the analogue specification for product innovators (column 8), the differential in the ICT-coefficient is smaller but significantly positive as well. 30

One might argue that the particular importance of innovations in the past is rather a consequence of technological opportunities than the impact of innovative experience. In particular, some businesses may be more suited than others to improve products or processes by the use of ICT. Those better suited businesses will both be able to reap higher productivity gains of ICT, but are more likely to be early adopters of ICT for restructuring their processes, too. If this is true, the higher productivity potentials found would be spurious. This argument would be a serious objection, indeed, if most of the 'experienced' firms in the sample belonged to the same ICT-suited industries. As can be seen from Table 3 in the appendix, however, the innovator shares do not vary greatly between industries. To illustrate this point in more detail, Table 4 in the appendix summarizes the share of experienced process innovators (epc) by industries at the more detailed NACE 2-digit level. ${ }^{31}$ In most of the industries, the share is quite close to the sample average of $45 \%$. ${ }^{32}$ This contradicts an eminent importance of technological opportunity as the driving force behind the results. 33

\footnotetext{
${ }^{28}$ The additional coefficient corresponds to $\beta_{6}$ of eq. 6 .

${ }^{29}$ In the corresponding one-step estimation, the significance level of the difference amounts to $p=0.068$ (see footnote 22).

${ }^{30}$ The significance level amounts to $\mathrm{p}=0.063$ in the two-step estimation and to even $\mathrm{p}=0.034$ in the one-step estimation (see footnote 22 ), confirming the results from column 3.

${ }^{31}$ The distribution of the innovator shares according to the alternative concepts are very similar (not reported).

${ }^{32}$ In 9 of the 13 industries, the corresponding share lies within the range of 35 and $55 \%$ and in two of the remaining four industries, the deviation from the sector mean may well be a consequence of the small number of observations available for these subsectors (NACE 61 with 6 and NACE 64 with 12 observations).

${ }^{33}$ In addition, one may argue that most innovations in business-related services are nowadays closely linked to the use of ICT. In this regard, innovative experience may reflect the specific capabilities gained from the early innovative use of ICT rather than a broad experience of various kinds of innovations. However, this argument is not an objection to the general argument of this study but raises the question how specific the innovative experience will be with respect
} 
A related objection may be that the results could be dominated by a higher productivity of ICT use in larger firms. From the innovation literature, it is well known that bigger firms are more likely to innovate (Cohen, 1998). The innovation proxies might therefore rather capture size effects. To address this issue, the robustness of the results has been checked in additional regressions in a translog-production function framework (not reported). Among other features, this more flexible framework explicitly controls for firm-size effects. ${ }^{34}$ Also in this specification the ICT coefficient turns out to be significantly higher in experienced firms. 35

Finally, it may be argued that apart from innovative experience, past innovations may reflect other firm characteristics like management ability and flexibility. Though certainly right, the impact of these underlying factors seems much more likely to be captured by the dummy for innovative experience than by the interaction of ICT and experience. That is, management characteristics are expected (and partially found) to have a direct impact on firm productivity and not so much on the productivity potentials of one of the particular factor inputs employed in the production process.

To sum up, there are three main findings that can be derived from the estimation results. First, innovative experience significantly matters for a productive use of ICT, whereas complementary innovations alone do not exhibit such an impact. Apparently, experience is a long-term strategic variable in contrast to rather ad-hoc introduced innovations within the firm. Obviously, it is mainly firms with an innovative 'tradition' that are most capable of exploiting the productivity potentials of ICT.

Second, experience gathered from past process and product innovations plays an important role with the impact of process innovations being quantitatively more substantial. This finding is consistent with theoretical arguments as well as with evidence from case studies which stress the particular importance of ICT for the re-engineering of business processes and the re-shaping of organizational structures within firms. ${ }^{36}$ Because of this close link, experience from past process innovations may help reduce the risks of innovation projects and will improve the firm's expectation formation with regard to the costs and benefits of ICT-induced changes.

to ICT (see footnote 2 on this topic). The empirical investigation of this issue is beyond the scope of this paper and is left to future research.

${ }^{34}$ See Hempell (2002) for further details on this specification.

${ }^{35}$ Moreover, if it was really firm-size that drives the results, the same link between firm size, innovation propensity and ICT elasticity would be expected to hold for innovators in general (including the wider definition as 'panel innovator'). However, for firms that have introduced an innovation in some period, the productivity effects of ICT were not found to be higher.

${ }^{36}$ In the service sector, organizational changes are closely linked to the introduction of new or improved processes. (See Hipp et al., 2000) 
Third, the dependence on innovative experience is a feature that distinguishes ICT investment from conventional capital. Thus, the increasing importance of continuous innovation may well be identified as a key characteristic of the so called 'New Economy'. Obviously, firms have not been equally prepared for the large range of innovation possibilities induced by the rapid diffusion of ICT. As a consequence, the induced wave of innovation has contributed to a widening of productivity differentials between firms.

\section{Conclusions}

In this paper, the productivity effects of ICT use in the German business-related and distribution services are analyzed with firm-level data. Based on an extended production function framework with labour and two types of capital inputs, a SYS-GMM estimator is employed in order to control for a variety of potential estimation biases, like unobserved heterogeneity, simultaneity of inputs and output and measurement errors. Various impacts and complementarities of ICT investment are identified. First, for a simple Cobb-Douglas specification in which all firms are treated equally, a significant output elasticity of ICT-capital of about 5\% is found, indicating substantial productivity effects of ICT in the German service sector in general. Secondly, based on a theoretical model, the production function framework is extended to allow productivity contributions of ICT capital to vary between firms. This more detailed analysis reveals that firms that have introduced process innovations in the past — labelled 'experienced' firms — are especially successful in ICT-use. The output elasticity of ICT in these firms amounts to about $15 \%$ and is significantly higher than for non-experienced firms (3\%). Third, opposite to the role of innovative experience, 'ad-hoc' implementations of innovations have no observable impacts on ICT productivity. Finally, it is found that the complementary role of innovative experience is a very specific characteristic of ICT since no such complementary link can be observed for investment in conventional capital. Taken together, these findings support the hypotheses developed in this paper which assign ICT the role of a 'special' capital input: unlike other capital goods, the productive use of ICT is closely linked to innovations in general and the re-engineering of processes in particular. Obviously, experience in process innovations is a crucial prerequisite for firms to meet the challenges of the so called 'New Economy'.

There are several implications of these findings concerning both theoretical and policy issues. At the theoretical level, the results contribute to a clarification of the role of ICT as a general purpose technology giving rise to complementary innovations. In spite of the diverse uses and the rapid diffusion of ICT throughout all industries, the productivity effects of ICT are far from self-enforcing but rather demand an active implementation strategy within firms. The role of 
innovative experience found in this paper indicates that the determinants for the efficient use of ICT belong to a firm's long-term strategies rather than being characteristics that can be changed easily in the short term. Innovative experience is likely to be acquired over years rather than within months.

Furthermore, the role of innovative history found at the micro level may also be useful for shedding more light on the differences of ICT-induced productivity effects found between countries. In fact, the competitive and innovative business environment in the U.S. may be one reason that helps explain why the productivity impact of ICT has been much higher there than in continental Europe. The higher innovation pressure in the U.S. over the last decades may have led firms to collect much more diverse innovative experience than the more protected firms in Europe. This may have enabled firms in the U.S. to reap higher benefits from the use of ICT. In this respect, ICT may have led to a further widening of the productivity gap both between the U.S. and Europe and between other regional parts of the world economy.

As far as economic policy is concerned, the findings of this paper point to the importance of an innovative business environment that is needed to lay the fundamentals for an efficient use of ICT. New technologies like ICT may be compared to the invention of a new fertilizer in farming: though its potential uses may be very general and its costs quite low, a sound climate, a cultivated soil and a gifted farmer will still be needed to actually increase crop yield. Unlike the case of farming, however, the climate in economics may be favoured to a large extent by sound policies. The results of this study suggest that enhancing competition and innovation incentives may serve as an important driver of both the rapid diffusion and a productive use of ICT. 


\section{References}

Arellano, M. and Bond, S. (1991). Some Tests of Specification for Panel Data: Monte Carlo Evidence and an Application to Employment Equations, Review of Economic Studies 58: 277-297.

Arellano, M. and Bond, S. (1998). Dynamic Panel Data Estimation Using DPD98 for GAUSS: A Guide for Users. ftp://ftp.cemfi.es/pdf/papers/ma/dpd98.pdf.

Arellano, M. and Bover, O. (1995). Another Look at the Instrumental Variable Estimation of ErrorComponents Models, Journal of Econometrics 68: 29-51.

Barras, R. (1986). Towards a Theory of Innovation in Services, Research Policy 15: 161-173.

Blundell, R. and Bond, S. (1998a). GMM Estimation with Persistent Panel Data: an Application to Production Functions, Working Paper Series No. W99/4, Institute for Fiscal Studies.

Blundell, R. and Bond, S. (1998b). Initial Conditions and Moment Restrictions in Dynamic Panel Data Models, Journal of Econometrics 87: 115-143.

Bresnahan, T. and Greenstein, S. (1996). Technical Progress and Co-invention in Computing and in the Uses of Computers, Brooking Papers on Economic Activity, Microeconomics pp. 1-77.

Bresnahan, T. F. and Trajtenberg, M. (1995). General Purpose Technologies: 'Engines of Growth'?, Journal of Econometrics 65: 83-108.

Bresnahan, T. F., Brynjolfsson, E. and Hitt, L. M. (2002). Information Technology, Workplace Organization, and the Demand for Skilled Labor: Firm-Level Evidence, Quarterly Journal of Economics 117: 339-376.

Brynjolfsson, E. and Hitt, L. M. (2000). Beyond Computation: Information Technology, Organizational Transformation and Business Performance, Journal of Economic Perspectives 14: 23-48.

Brynjolfsson, E. and Yang, S. (1999). The Intangible Costs and Benefits of Computer Investments: Evidence from the Financial Markets, Proceedings of the International Conference on Information Systems, Atlanta, Georgia, MIT Sloan School.

Cohen, W. (1998). Empirical Studies of Innovative Activity, in P. Stoneman (ed.), Handbook of the Economics of Innovation and Technological Change, 3rd edn, Blackwell, Oxford UK \& Cambridge USA, chapter 6, pp. 182-264.

Cohen, W. M. and Levinthal, D. A. (1990). Absorptive Capacity: A New Perspective on Learning and Innovation, Administrative Science Quartely 35: 128-152. 
Colecchia, A. and Schreyer, P. (2001). ICT Investment and Economic Growth in the 1990s: Is the United States a Unique Case?, STI Working Papers 2001/\%, OECD.

EITO (2001). European Information Technology Observatory 2001, EITO, Frankfurt/Main.

Flaig, G. and Stadler, M. (1994). Success Breeds Success — The Dynamics of the Innovation Process, Empirical Economics 19: 55-68.

Fraumeni, B. M. (1997). The Measurement of Depreciation in the U.S. National Income and Product Accounts, Survey Of Current Business 77/7: 7-23.

Griliches, Z. (1994). Productivity, R\&D, and the Data Constraint, American Economic Review 84: $1-23$.

Hall, B. H. and Mairesse, J. (1995). Exploring the Relationship Between R\&D and Productivity in French Manufacturing Firms, Journal of Econometrics 65: 263-293.

Hempell, T. (2002). What's Spurious, What's Real? Measuring the Productivity of ICT at the Firm-Level, ZEW Discussion Paper 02-42, Centre for European Economic Research.

Hipp, C., Tether, B. S. and Miles, I. (2000). The Incidence and Effects of Innovation in Services: Evidence from Germany, International Journal of Innovation Management 4(4): 417-454.

Hoffmann, J. (1998). Problems of Inflation Measurement in Germany, Discussion Paper No. 01-98, Economic Research Centre of the Deutsche Bundesbank.

Janz, N., Ebling, G., Gottschalk, S. and Niggemann, H. (2001). The Mannheim Innovation Panels (MIP and MIP-S) of the Centre for European Economic Research (ZEW), Schmollers Jahrbuch 121: $123-129$.

Jorgenson, D. W. and Stiroh, K. (1995). Computers and Growth, Economics of Innovation and New Technology 3: 295-316.

Lehr, B. and Lichtenberg, F. (1999). Information technology and its impact on productivity: Firmlevel evidence from government and private data sources, Canadian Journal of Economics 32(2): 335-362.

Mansfield, E. (1968). Industrial Research and Technological Innovation: An Econometric Analysis, Norton, New York.

Moulton, B. R., Parker, R. P. and Seskin, E. P. (1999). A Preview of the 1999 Comprehensive Revision of the National Income and Product Accounts - Definitional and Classificational Changes, Survey of Current Business 79: 7-20. 
Müller, A. A. (1998). Kapitalstock und Produktionspotential im privaten und öffentlichen Sektor Deutschlands, Nomos, Baden-Baden.

Nelson, R. R. (1982). The Role of Knowledge in R\&D Efficiency, Quarterly Journal of Economics 97/3: 453-470.

Nelson, R. R. and Winter, S. (1982). An Evolutionary Theory of Economic Change, Harvard University Press, Cambridge MA.

OECD (2000a). A New Economy? The Changing Role of Innovation and Information Technology in Growth, OECD, Paris.

OECD (2000b). The Service Economy, Business and Industry Policy Forum Series, STI/OECD.

Pavitt, K. (1984). Sectoral Patterns of Technical Change: Towards a Taxonomy and a Theory, Research Policy 13: 343-373.

Schreyer, P. (2000). The Contribution of Information and Communication Technology to Output Growth: A Study of the G7 Countries, STI Working Paper 2000/2, OECD.

Sirilli, G. and Evangelista, R. (1998). Technological Innovation in Services and Manufacturing: Results from Italian Surveys, Research Policy 27: 881-899.

Smith, M. D. and Brynjolfsson, E. (2001). Consumer Decision-Making at an Internet Shopbot: Brand Still Matters, Journal of Industrial Economics 49: 541-558.

Stoneman, P. (1983). The Economic Analysis of Technological Change, Oxford University Press, Oxford. 


\section{Appendix}

\section{A Construction of ICT and non-ICT capital stocks}

For the purpose of the empirical analysis within the production function framework, capital stocks for conventional (non-ICT) capital and ICT capital are constructed separately from investment data applying the perpetual inventory method as follows. The capital stock $K_{k t}$ of type $k$ in period $t$ results from investment $I_{k, t-1}$ in the following way:

$$
K_{k t}=\left(1-\delta_{k}\right) K_{k, t-1}+I_{k, t-1}
$$

with $k=1$ for conventional and $k=2$ for ICT capital and investment.

There are two particular issues to be addressed in this approach. First, reasonable values for the depreciation rates of both types of capital have to be defined. Second, since no information is available on the level of capital stocks, initial capital stocks have to be constructed for all individual firms. Therefore, the method proposed by Hall and Mairesse (1995) for the construction of R\&D stocks is applied. Under the assumption that investment expenditures in capital good $k$ have grown at a similar, constant average rate $g_{k}$ in the past for all firms, equation (7) can be rewritten for period $t=1$ (1994) by backward substitution in the following way: 37

$$
\begin{aligned}
K_{k 1} & =I_{k 0}+\left(1-\delta_{k}\right) I_{k,-1}+\left(1-\delta_{k}\right)^{2} I_{k,-2}+\ldots \\
& =\sum_{s=0}^{\infty} I_{k,-s}\left(1-\delta_{k}\right)^{s}=I_{k 0} \sum_{s=0}^{\infty}\left[\frac{1-\delta_{k}}{1+g_{k}}\right]^{s} \\
& =\frac{I_{k 1}}{g_{k}+\delta_{k}}
\end{aligned}
$$

Constant linear depreciation rates are assumed for conventional capital $\left(\delta_{1}\right)$ and ICT capital $\left(\delta_{2}\right)$ correspondingly. For $\delta_{1}$, the average depreciation rates by industries at the NACE two-digit level over the years 1991-1999 are employed ${ }^{[38}$ For ICT capital, a depreciation rate of $30 \%$ is assumed..$^{39}$

\footnotetext{
${ }^{37}$ In fact, the initial value of investment in conventional capital $I_{1,1}$ is replaced by the average of the observed values of conventional investment for each firm. This "smoothing" is aimed at correcting for cyclical effects which might have affected the estimated capital stock due to different initial years in the unbalanced panel. The underlying assumption is that long term growth of investment in conventional capital ( $g_{1}=0.05$, see footnote 40) is relatively low compared to cyclical variations in this variable. On the contrary, the first observation on ICT capital was not replaced by the corresponding averages since long-term growth $\left(g_{2}=0.4\right.$, see main text below) rates of ICT investment are more likely to dominate changes due to cyclical fluctuations.

${ }^{38}$ The depreciation rates by industries are calculated as the shares of capital consumption in net fixed assets evaluated at replacement prices as given by the time series 7719 and 7735 of the German Statistical Office. The resulting depreciation rates hardly vary over time such that averaging over time is of minor importance. The unweighted mean over all service industries amounts to $9 \%$ with a maximum in the NACE 72 (data processing) of $21 \%$ and a minimum in NACE 70 (real estate) with $2.2 \%$.

${ }^{39}$ Relying on available data from the U.S. indicated by Fraumeni (1997) and Moulton, Parker and Seskin (1999), depreciation rates for IT-hardware, software and telecommunication capital are assumed to be $31.2 \%$ for IT-hardware, $55.0 \%$ for prepackaged software, $33.0 \%$ for custom and own-account software and $15.0 \%$ for telecommunication capital.
} 
In particular, by assuming $\delta_{1}<\delta_{2}$ it is taken into account that the fast technological progress in ICT implies more frequent replacement of ICT inventory than of conventional capital (including buildings and office furniture among others). In order to derive the initial capital stocks, assumptions about pre-period growth rates of both types of investments must be made. For non-ICT investment expenditures, an annual growth rate of approximately $5 \%\left(g_{1}=0.05\right)$ is assumed 40 For ICT investment, no time series are available for Germany. In order to get a rough idea of the evolution of ICT investments during the last decades, U.S. data is used as a rough guideline. Jorgenson and Stiroh (1995) calculate an average annual growth rate of $44.3 \%$ in real computer investment and of $20.2 \%$ for OCAM (office, computing, and accounting machinery) between 1958 and 1992 for the U.S. Since the share of computers in OCAM has been rising continuously — reaching 94\% in 1992 -, an annual pre-period growth rate close to the growth rate of computer investment of $g_{2}=0.4$ is assumed for ICT investment. ${ }_{41}^{41}$ Since there are time lags between the installation and the productive contribution of capital goods, the capital stocks at each period's beginning (or at the end of the corresponding previous period) are taken as measures for both ICT and conventional capital input.

Some 45 firms reported a share of ICT investment in total investment expenditures equal to zero for all the periods surveyed. Since the econometric specification is in logs, these firms, in which ICT can be expected to have low productivity impacts, would have to be excluded from the sample. However, it seems more likely that ICT investment in these firms is not zero, in fact, but rather very low and rounded to zero by the respondents. In order to prevent potential biases in the results the ICT stock per worker is assumed to be equal to the corresponding industry minimum in these cases and the corresponding values are imputed. Robustness checks show that the qualitative results found in this paper are independent of these imputations.

Using data by EITO (2001) for the year 1999, total ICT investment expenditures in Germany consist of $47.0 \%$ for IT-hardware, $26.9 \%$ for software and $26.1 \%$ for end-user and network telecommunication equipment. The weighted mean of depreciation rates — with the market shares as weights - yields an average depreciation rate of ICT capital of $\delta_{1}=0.312 \cdot 0.47+(0.55+0.33) / 2 \cdot 0.269+0.15 \cdot 0.261=0.304$.

40 Calculations on capital data provided by Müller (1998) show that gross capital stock in German services has grown on average by $4.8 \%$ annually between 1980 and 1991 .

${ }^{41}$ In fact, later results in the production function estimates turned out to be robust to variations in both $g$ and $d$. 


\section{B Tables}

Table 2: Summary statistics

\begin{tabular}{lccccccc}
\hline \hline & & & & & \multicolumn{3}{c}{ percentiles } \\
& mean & std. & min. & max. & $10 \%$ & $50 \%$ & $90 \%$ \\
\hline \hline value added* $_{\text {employees }}$ & 53.145 & 705.526 & 0.012 & $27,380.080$ & 0.351 & 2.495 & 39.805 \\
ICT capital* & 596.7 & 9224 & 1 & 310792 & 7 & 40 & 499 \\
non-ICT capital* & 4.892 & 129.075 & $<0.001$ & $6,537.479$ & 0.004 & 0.045 & 0.892 \\
East German (dummy) & 0.422 & 0.494 & 0 & 1 & 0 & 0 & 1 \\
\hline
\end{tabular}

*measured in million Euro; sample with 5107 observations from 1222 firms

Table 3: Share of innovators by industries (percentages)

\begin{tabular}{lccccc} 
industry & ppc & ppd & epc & epd & both epc \& epd \\
\hline \hline wholesale trade & 64.5 & 75.6 & 37.2 & 52.3 & 33.7 \\
retail trade & 63.2 & 70.0 & 37.9 & 47.9 & 32.1 \\
transport and postal services & 69.8 & 78.4 & 50.0 & 55.0 & 45.0 \\
electronic data processing and telecom. & 90.0 & 97.0 & 60.0 & 78.0 & 57.0 \\
consultancies & 82.5 & 83.5 & 54.4 & 62.1 & 48.5 \\
technical services & 84.6 & 84.6 & 58.7 & 61.5 & 47.6 \\
other business-related services & 67.1 & 75.3 & 37.0 & 49.7 & 32.2 \\
\hline all industries & 71.9 & 78.6 & 45.4 & 55.5 & 39.9
\end{tabular}

Table 4: Share of firms with process innovation experience by NACE at the 2-digit level

\begin{tabular}{lccccccccccccc} 
industry* $^{*}$ & 50 & 51 & 52 & 60 & 61 & 63 & 64 & 70 & 71 & 72 & 73 & 74 & 90 \\
\hline epc firms (\%)** & 37 & 37 & 39 & 45 & 67 & 52 & 58 & 34 & 32 & 60 & 47 & 49 & 48 \\
\hline \# firms & 71 & 172 & 119 & 88 & 6 & 121 & 12 & 83 & 19 & 95 & 17 & 355 & 64 \\
* defined at NACE & 2-digit level, & ** share of firms that are experienced process innovators
\end{tabular}


Table 5: Comparison of sample and population by industries

\begin{tabular}{lcccc}
\hline & & \multicolumn{2}{c}{ sample } & population* \\
\hline industry & NACE-digit & \# firms & share (\%) & share (\%) \\
\hline wholesale trade & 51 & 172 & 14.1 & 10.6 \\
retail trade & 50,52 & 190 & 15.6 & 31.3 \\
transport and postal services & $60-63,64.1$ & 222 & 18.2 & 11.7 \\
electronic processing and telecom. & $72,62.2$ & 100 & 8.2 & 3.4 \\
consultancies & $74.1,74.4$ & 103 & 8.4 & 12.1 \\
technical services & $73,74.2,74.3$ & 152 & 11.7 & 10.7 \\
other business-related services & $70,71,74.5-.8,90$ & 292 & 23.9 & 20.3 \\
\hline all industries & & 1222 & 100 & 100 \\
\hline
\end{tabular}

*German service firms with 5 and more employees in 1999.

Source: German Statistical Office, ZEW and own calculations

Table 6: Comparison of sample and population by size classes

\begin{tabular}{lcccc}
\hline & \multicolumn{2}{c}{ full sample } & \multicolumn{2}{c}{ population* } \\
\hline $\begin{array}{l}\text { size class } \\
\text { (\# employees) }\end{array}$ & \# firms & firms (\%) & firms (\%) & sales $(\%)$ \\
\hline $5-9$ & 205 & 16.8 & 57.6 & 9.4 \\
$10-19$ & 206 & 16.9 & 24.0 & 9.9 \\
$20-49$ & 254 & 20.8 & 11.7 & 9.7 \\
$50-99$ & 156 & 12.8 & 3.5 & 6.9 \\
$100-199$ & 168 & 13.8 & 1.6 & 6.0 \\
$200-499$ & 102 & 8.3 & 1.0 & 7.0 \\
500 and more & 131 & 10.7 & 0.6 & 51.1 \\
\hline all size classes & 1222 & 100 & 100 & 100 \\
\hline
\end{tabular}

*German service firms with 5 and more employees in 1999.

Source: German Statistical Office, ZEW and own calculations

Table 7: Means and median of capital and output intensity of production for the full sample

\begin{tabular}{lcccccc}
\hline & \multicolumn{2}{c}{ all firms } & \multicolumn{2}{c}{ experienced (epc) } & \multicolumn{2}{c}{ not experienced } \\
& mean & median & mean & median & mean & median \\
\hline \hline ICT per worker & 3,801 & 1,302 & 4,633 & 1,902 & 3,109 & 830 \\
non-ICT per worker & 226,947 & 25,574 & 192,465 & 23,535 & 255,640 & 27,032 \\
value added per worker & 122,198 & 60,575 & 118,075 & 57,008 & 125,628 & 64,680 \\
\hline \# firms & \multicolumn{2}{c}{1222} & \multicolumn{2}{c}{667} & \multicolumn{2}{c}{555} \\
\hline
\end{tabular}

Values in Euro in prices of 1996. The figures are calculated as the mean and median of the unweighted firms' means over time, based on the full sample of 1222 firms. 
Table 8: The effects of including human capital

\begin{tabular}{lcc}
\hline & & Dep. Variable: sales (logs) \\
\hline inputs (logs) & small & small w. skill \\
\hline \hline labour & $0.737^{* * *}$ & $0.656^{* * *}$ \\
& $(0.122)$ & $(0.063)$ \\
ICT capital & 0.015 & 0.017 \\
& $(0.050)$ & $(0.040)$ \\
non-ICT capital & $0.168^{* *}$ & $0.208^{* * *}$ \\
& $(0.077)$ & $(0.051)$ \\
East-Germany & $-0.327^{* * *}$ & $-0.416^{* * *}$ \\
& $(0.074)$ & $(0.066)$ \\
\% university & - & $0.827^{* * *}$ \\
& & $(0.194)$ \\
\%vocational & - & $0.475^{* * *}$ \\
& & $(0.120)$ \\
\hline observations & 1887 & 1887 \\
number of firms & 591 & 591 \\
R-square & 0.825 & 0.836 \\
Wald statistics[df] & & \\
inputs & $224[4]$ & $497[6]$ \\
time and ind. dummies & $393[34]$ & $449[34]$ \\
Sargan (p-values) & 0.591 & 0.198 \\
errors (p-values): & & \\
AR(1) & 0.024 & 0.029 \\
AR $(2)$ & 0.146 & 0.163 \\
\hline$* * * * * *$ significant at the 1,5 and 10 per cent level & \\
R & &
\end{tabular}

$* * *, * *, *=$ significant at the 1,5 and 10 per cent level

Regression results are based on the two-step SYS-GMM estimator and contain a constant and industry dummy variables interacted with year dummy variables.

Heteroscedasticity consistent standard errors reported. 